Khazanah: Jurnal Studi Islam dan Humaniora

ISSN: 0215-837X (p); 2460-7606 (e), Vol. 18 (1), 2020, pp. 91-108

DOI: $10.18592 /$ khazanah.v18i1.3499

Submit :14/01/2020 Review : 03/06/2020 Publish : 20/06/2020

\title{
KENABIAN DALAM PANDANGAN BADIUZZAMAN SAID NURSI: SEBUAH RESPON TERHADAP GAGASAN MATERIALISME BARAT
}

\author{
Fuad Mahbub Siraj; Muhammad Husni \\ Universitas Paramadina Jakarta \\ fuad.siraj@paramadina.ac.id; Husni5794@gmail.com
}

\begin{abstract}
This study aims to further explain Badiuzzaman Said Nursi's thought on prophethood. This library study employs a historical approach in extracting data and content analysis. The study shows that Said Nursi's thought concerning prophecy stems from his criticisms of the materialistic-mechanistic paradigm of Western civilization. This view basically rejects the transcendental perspective and spiritual values in understanding nature. The notion of materialism from the West attacks the key concepts of Islamic teachings. Realizing this, Nursi was called upon to give a very serious intellectual response. It was at this point that Nursi offered his ideas on prophethood. In Risalah an-Nur, Said Nursi strives to revive prophetic values by applying theological approaches to be easily understood by society. Nursi's thought is built on an effort to revive prophetic values so that it could shed light on Turkish people who had suffered serious illnesses due to the influences of the Western paradigm of mechanical materialism. This prophetic knowledge would eventually end in faith, which leads to eternal happiness for believers and eternal misery for unbelievers.
\end{abstract}

Keyword: Bediuzzaman Said Nursi; Materialism; Risalah an-Nur; Prophethood; Sprituality

\begin{abstract}
Abstrak: Artikel ini bertujuan untuk lebih menjelaskan pemikiran Badiuzzaman Said Nursi tentang kenabian. Studi literatur ini menggunakan pendekatan historis dalam mengekstraksi data dan melakukan analisis konten. Studi ini menunjukkean babwa pemikiran Said Nursi tentang nubuat berasal dari kritiknya terhadap paradigma materialisme-mekanistik peradaban Barat. Pandangan ini pada dasarnya menolak perspektif transendental dan nilai-nilai spiritual dalam memahami alam. Gagasan materialisme dari Barat menyerang konsep-konsep kunci ajaran Islam. Menyadari hal ini, Nursi dipanggil untuk. memberikan respons intelektual yang sangat serius. Pada titik inilab Nursi menawarkan gagasannya tentang kenabian. Dalam Risalah an-Nur, Said Nursi berusaba untuk menghidupkan kembali nilai-nilai kenabian dengan menerapkan pendekatan teologis agar mudab dipabami oleh publik. Pemikiran Bediuzzaman dibangun dalam upaya untuk menghidupkan kembali nilai-nilai kenabian sehingga dapat memberikan cahaya kepada orang-orang Turki yang sudab menderita penyakit serius karena pengaruh Barat dengan paradigma materialisme mekanis yang tidak memiliki dimensi spiritualitas. Pengetahuan kenabian ini pada akbirnya akan berakhir dalam iman, yang oleh Bediuzzaman disebut kebahagiaan esensial (manusia memiliki iman) bagi manusia, dan yang menolak (kufur) keberadaan peran Tuban dan Nabi, yang merupakan kesengsaraan sejati.
\end{abstract}

Kata kunci: Badiuzzaman Said Nursi; Materialisme; Risalah an-Nur; Kenabian; Spritualitas.

\section{Pendahuluan}

Gagasan materialisme dan positivisme telah banyak dianut oleh banyak intelegensia Turki pada paruh kedua abad ke-19 Masehi dan bahkan telah berhasil memasuki banyak sekolah. Lebih jauh, pandangan materialisme dan positivisme 
ditawarkan menjadi filsafat yang diajarkan secara resmi di setiap jenjang pendidikan. Terdapat banyak filosof materialis Eropa yang sangat berpengaruh serta dijadikan referensi dalam dunia pemikiran dan pendidikan Turki, diantaranya: Auguste Comte, Claude Bernand, Charles Darwin, dan juga Ludwig Buncher. ${ }^{1}$

Di bawah pengaruh pandangan materialisme, para pemikir Turki Usmani mendeklarasikan beberapa hal berikut: pertama, alam semesta ini terbentuk dari materi dan bekerja sendiri seperti mesin. Selain itu, mereka juga sangat meyakini pemisahan agama, spiritualitas, dan tradisi dari ilmu pengetahuan. Pandangan ini diambil dari gagasan positivisme Comte, materialisme Bacon serta Newton; kedua, manusia pada hakikatnya tidak memiliki dimensi spiritual. Pandangan ini diambil dari gagasan materialisme jiwa Bernand; ketiga, manusia merupakan puncak dari proses evolusi. Pandangan ini diambil dari gagasan evolusi Darwin; dan keempat, materi itu bersifat abadi. Pandangan ini diambil dari gagasan materialisme Buncher. ${ }^{2}$

Secara massif, gagasan materialis terus mengakar di zaman kekaisaran Turki Utsmani melalui pendirian lembaga pendidikan modern yang dibuka secara berturutturut pada abad ke-19. Hampir semua pemikir materialis Turki dididik di lembagalembaga pendidikan modern. Salah satu institusi pendidikan yang paling terkenal adalah Sekolah Kedokteran (Mekteb-i Tibbiye) Turki yang menjadi kiblat ide materialis saat itu. Di dalam lembaga pendidikan yang telah mengalami sekularisasi ini, banyak karya-karya pemikir materialis Eropa diterjemahkan ke dalam Bahasa Turki. Selain itu, banyak lulusannya dikirim ke Eropa untuk mempelajari materialisme dan kembali ke Turki untuk menyebarkannya ke tengah-tengah masyarakat. Beberapa intelektual Turki yang dapat disebut dalam konteks ini, yaitu: Basyir Fuad, Ahmad Syuaib, Baha Taufik, Subhi Ethem, dan juga Abdullah Jaudat. Mereka semua adalah lulusan Mekteb$i$ Tibbiye yang merupakan pendiri dari CUP (Committee of Union and Progress). ${ }^{3}$ CUP adalah kelompok pemikir Turki yang mempromosikan gagasan materialisme, sekulerisme, dan positivisme. CUP memandang bahwa agama dan tradisi, dalam hal ini Islam adalah simbol keterbelakangan dan penghambat kemajuan. ${ }^{4}$

Abdullah Jaudat, misalnya, menyatakan beberapa pandangan berikut: pertama, nilai tertinggi dan teragung adalah sains; kedua, manusia dan alam hanya bisa dipahami melalui metode saintifik; ketiga, agama dan tradisi adalah faktor yang melemahkan bangsa serta bertentangan dengan kemajuan; keempat, sains dan agama pada hakikatnya bertentangan; kelima, sumber kemajuan peradaban adalah nilai-nilai modern Barat yang menolak agama dan tradisi. ${ }^{5}$

Badiuzzaman Said Nursi, seorang ulama-intelektual Turki, merespons pemikiran para penganut materialisme tersebut. Said Nursi telah menyaksikan dan

${ }^{1}$ Musa al-Basit, Said Nursi's Approach to The Stories of The Qur'an. In A Contemperary Approach to

Understanding The Qur'an: The Example of The Risale-i Nur (Istanbul: Sozler Nesyriyyat, 2000), 614-615.

${ }^{2}$ Ibid.

${ }^{3}$ Ibid.

"4 Sukran Vahide, Biografi Intelektual Badi'uzzaman Said Nurs; Transformasi Dinasti Usmani Menjadi Republik Turki (Jakarta: Anatolia, 2007), 49.

5al-Basit, Said Nursi's Approach to The Stories of The Qur'an. In A Contemperary Approach to Understanding The Qur'an: The Example of The Risale-i Nur. 
merasakan, ilmu dan filsafat menjadi sarana yang menakutkan, sebab ilmu dan filsafat yang mereka bawa tersebut telah mengarahkan manusia kepada sikap atheis

Sebagai seorang pemikir muslim, Said Nursi berhasil mengenali materialisme yang merupakan buah dari modernitas, serta ia menawarkan kontribusi yang amat bernilai dalam upaya mengungkapkan pendekatan intelektual dan spiritual Islam untuk menyoroti penyebab kesalahan dalam memahami dan salah mengartikan pemikiran mereka. Gagasan materialisme menolak dimensi sakral dan sisi pendekatan spiritualitas, maka secara umum gagasan religius, dan khususnya gagasan kenabian tidak memiliki ruang. Pada titik inilah Nursi menawarkan gagasannya mengenai kenabian. Lebih lanjut melalui pemikiran kenabiannya, Said Nursi ingin mengajak masyarakat Islam, khususnya masyarakat Islam Turki untuk memperbaiki keimanan kepada Allah melalui pemahaman terhadap risalah kenabian yang diperlihatkan Said Nursi tidak saja melalui tulisan, melainkan juga dalam aplikasi kehidupan keseharian.

\section{Metode}

Penelitian ini adalah penelitian kepustakaan dengan menggunakan pendekatan historis dalam menggali data serta melakukan analisis atas konten. Penelitian ini akan menjelaskan lebih lanjut mengenai pemikiran kenabian Said Nursi sebagai sebuah respon terhadap gagasan materialisme Barat.

Sebagai Pembaharu dan intelektual yang sangat berpengaruh di abad 20, Badiuzzaman Said Nursi telah mengundang banyak sarjana dan peneliti untuk mengkaji pemikiran dan biografinya. Sukran Vahide ${ }^{6}$ dan Ihsan Kasim Salih ${ }^{7}$ menulis dengan cukup sistematis biografi intelektual Said Nursi. Buku biografi yang ditulis oleh Vahide memperlihatkan indikasi bagaimana kekaguman pribadinya terhadap sosok Said Nursi sehingga Vahide tidak sepenuhnya memberikan kritik atas banyaknya tulisan Nursi. Vahide bisa disebut berhasil dalam menjelaskan Nursi, namun ia juga terjebak dalam sebuah keyakinan bahwa karya Risalah al-Nur Said Nursi adalah ilham Tuhan dan bukan refleksi dari Said Nursi. Penelitian Parid Ridwanuddin menyorot pemikiran Said Nursi pada dimensi ekoteologi. ${ }^{8}$ Muhammad Faiz dan Ibnor Azli Ibrahim melihat unsur sufisme dalam konsep pendidikan Said Nursi. ${ }^{9}$ Alkan Junaidi membicarakan eksistensi Tuhan dalam pemikiran Said Nursi. ${ }^{10}$ Muhammad Faiz menjelaskan mengenai Risalah Nur dan Gerakan Tarekat di Turki dan melihat bagaimana peran Said Nursi pada awal pemerintahan republik. ${ }^{11}$ Ilyas Fahmi

'Sukran Vahide, Biografi Intelektual Badi'uzzaman Said Nurs; Transformasi Dinasti Usmani Menjadi Republik Turki (Jakarta: Anatolia, 2007).

7hsan Kasim Salih, Said Nursi Pemikir Dan Sufi Besar Abad 20 (Jakarta: Murai Kencana, 2003).

8Parid Ridwanuddin, "Ekoteologi Dalam Pemikiran Badiuzzaman Said Nursi," LENTERA: Jurnal Ilmu Dakwah dan Komunikasi 1, no. 01 (May 12, 2017), doi:10.21093/lentera.v1i01.832.

${ }^{9}$ Muhammad Faiz and Ibnor Azli Ibrahim, "Unsur Sufisme Dalam Konsep Pendidikan Said Nursi" 4, no. 2 (2015): 16.

${ }^{10}$ Alkan Junaidi, "Eksistensi Tuhan Menurut Said Nursi” 1, no. 1 (2016): 9.

${ }^{11}$ Muhammad Faiz, "Risalah Nur Dan Gerakan Tarekat Di Turki: Peran Said Nursi Pada Awal Pemerintahan Republik," Al-A'raf: Jurnal Pemikiran Islam dan Filsafat 14, no. 1 (June 27, 2017): 23, doi:10.22515/ajpif.v14i1.588. 
Ramadlani menyorot bagaimana perjuangan Badiuzzaman Said Nursi dalam dalam membendung arus sekularisasi di Turki. ${ }^{12}$ Muhammad Labib Syauqi berbicara mengenai Risalah Nur Karya Badiuzzaman Said Nursi dan Metodologi Penafsirannya. ${ }^{13}$ Hamid Fahmi Zarkasy dan kawan-kawan lebih menyorot bagaimana konsep psikoterapi Badiuzzaman Said Nursi dalam Risalah an-Nur. ${ }^{14}$ Berdasarkan penelusuran penulis belum ditemukan bahasan khusus pemikiran kenabian Said Nursi. Penelitian yang dilakukan lebih banyak terkait kepada isu ketuhanan, pendidikan, teologis dan sufisme.

\section{Pembahasan}

\section{Kenabian Sebagai Kritik Terhadap Materialisme Mekanik}

Pemikiran Said Nursi mengenai kenabian terdapat pada tiga kitab, yakni alKalimāt, kitab al-Maktubāt dan kitab al-Lama'ä. Kitab-kitab tersebut pada prinsipnya bukanlah kitab yang memang khusus untuk membicarakan kenabian, namun dalam kitab tersebut terdapat bahasan-bahasan yang bisa dijadikan rujukan dalam memperlihatkan pemikiran Said Nursi mengenai kenabian.

Pemikirannya Said Nursi mengenai kenabian, bermula dari paradigma materialisme-mekanistik yang dilahirkan dari rahim peradaban Barat. Pandangan ini pada hakikatnya menolak perspektif transendental dan nilai-nilai spiritual dalam memahami alam. ${ }^{15}$ Dalam bahasa lain, materialisme-mekanistik adalah filsafat yang tidak mengakui peran Tuhan, sekaligus menolak kenabian. Sebab, menolak Tuhan berarti menolak nabi yang membawa ajaran dari Tuhan.

Bagi mereka (penganut Materialisme), realitas satu-satunya adalah materi dan segala sesuatu merupakan aktivitas dan manifestasi dari materi. ${ }^{16}$ Paham ini berprinsip bahwa di dunia tidak ada selain materi, atau bahwa nature (alam) dan dunia fisik adalah satu. Ide materialisme dapat dirunut kepada seorang filsuf alam Yunani klasik yaitu Democritus. Democritus berpendapat bahwa alam terdiri dari dua unsur fundamental: atom dan ruang hampa. Karena ia tidak mempercayai apapun kecuali benda-benda material, ia disebut seorang filsuf materialis ${ }^{17}$ pertama yang ide-idenya dilanjutkan oleh Epicurus dan Lucretius.

Doktrin materialisme menemukan momentumnya pada awal abad modern di tangan Thomas Hobbes dengan menyajikan materialisme yang mekanik seluruhnya. ${ }^{18}$

\footnotetext{
${ }^{12}$ Ilyas Fahmi Ramadlani, "Perjuangan Badiuzzaman Said Nursi dalam Membendung Arus Sekularisasi di Turki," Nalar: Jurnal Peradaban dan Pemikiran Islam, 3, no. 1 (2019): 8.

${ }^{13}$ Muhammad Labib Syauqi, "Mengenal Risalah Nur Karya Said Nursi Dan Metodologi Penafsirannya," MAGHZA: Jurnal Ilmu Al-Qur'an dan Tafsir 2, no. 1 (May 25, 2018): 109-24, doi:10.24090/maghza.v2i1.1547.

${ }^{14}$ Hamid Fahmy Zarkasyi et al., "Konsep Psikoterapi Badiuzzaman Said Nursi dalam Risale-i Nur,” TS AQAFAH 15, no. 2 (November 4, 2019): 215, doi:10.21111/tsaqafah.v15i2.3379.

15al-Basit, Said Nursi's Approach to The Stories of The Qur'an. In A Contemperary Approach to Understanding The Qur'an: The Example of The Risale-i Nur, 682-684.

${ }^{16}$ Lorens Bagus, Kamus Filsafat (Jakarta: Gramedia, 2005), 594.

${ }^{17}$ Jostein Gaarder, Dunia Sophie (Bandung: Mizan, 1997), 60-63.

${ }^{18}$ Harold H Titus, Persoalan-Persoalan Filsafat (Jakarta: Bulan Bintang, 1984), 296.
} 
Hobbes juga dipandang sebagai perintis empirisme modern yang mengembalikan pengetahuan pada pengalaman dan berusaha membebaskan diri dari bentuk-bentuk spekulasi spiritual dalam metafisika tradisional. Ia menegaskan bahwa filsafat tidak berurusan dengan ajaran-ajaran teologis. Yang menjadi objek filsafat adalah yang dapat dialami oleh tubuh. Kalau ada substansi yang tak berubah-ubah, yaitu Allah, dan juga substansi yang tak bisa diraba harus disingkirkan dari refleksi filosofis. ${ }^{19}$

Berujung pada paham positivisme yang dicetuskan oleh Auguste Comte pada awal abad 19. Karena itu, positivisme merupakan ahli waris empirisme yang sudah diradikalkan. ${ }^{20}$ Bagi seorang pengikut aliran materialisme, alam dipandang ibarat sebuah mesin yang tidak memiliki nilai intrinsik pada dirinya sendiri, selain nilai instrumental sekedar demi kepentingan manusia. Cara pandang ini melahirkan sikap dan perilaku yang eksploitatif serta tidak peduli kepada alam. Manusia lalu bertindak sewenang-wenang terhadap alam dan yang berlaku adalah kalkulasi ekonomi yang memperlakukan alam sebagai pemuas kepentingan dan nafsu manusia.

Dalam hubungannya dengan dunia Islam, paham materialisme inilah yang dibawa masuk bangsa Eropa (Inggris) ke tengah-tengah bangsa Turki pada akhir abad 19 hingga pertengahan abad 20. Ironinya, kebanyakan masyarakat awam terpikat dengan doktrin-doktrin materialisme tersebut yang akhirnya mengantarkan mereka bersikap ateis.

Dalam Risalah an-Nur, Said Nursi berusaha untuk menghidupkan kembali nilai-nilai kenabian dengan menerapkan pendekatan teologis agar mudah dipahami oleh masyarakat. Pemikiran Nursi dibangun dengan usaha untuk menghidupkan kembali nilai-nilai kenabian. Hal ini dimaksudkan untuk memberikan cahaya kepada masyarakat Turki yang sudah mengidap penyakit berat akibat pengaruh Barat dengan paradigma materialisme Mekanik yang tidak memiliki dimensi spiritualitas. Oleh karena itu, Said Nursi mengkategorikan Barat kepada dua macam: 1. Barat yang rajin, tekun, kreatif, inovatif, kerja keras demi mencapai dunia ini. 2. Barat acuh tak acuh, tidak peduli, lalai dari soal ketuhanan. Barat pada kategori pertama, bagi Nursi itu sudah umum, dan oleh sebab itu ia tidak mengelaborasi terlalu jauh soal ini. Namun, Barat kategori kedua inilah yang dikritik oleh Nursi, agar tradisi ini tidak menjadi kecendrungan manusia seluruhnya, termasuk dalam Islam. Maka dari itu, Nursi menantang Barat untuk membaca risalahnya, agar dapat terhindar dari kesesatan yang sudah sangat terstruktur mengitari hidup mereka. ${ }^{21}$

Menurut Nursi, Islam lebih unggul dari Barat dalam aspek spritualitas. Kekeringan spritualitas di Barat bersumber dari filsafat materialisme dan ateisme. Dalam Islam, keunggulan wahyu atas filsafatlah yang menjadi dasar atas spritualitas Islam. Tuhan hanya bisa dikenali dengan wahyu dan akal terbatas untuk sampai padaNya. Wahyu dan filsafat, menurut Nursi, telah lama "bertempur" untuk menduduki

${ }^{19}$ F. Budi Hardiman, Filsafat Modern (Jakarta: Gramedia, 2007), 67.

${ }^{20}$ Ibid., 205.

${ }^{21}$ Badi'uzzaman Said Nursi, Al-Matsnawi al-'Arabi al-Nuri (Jakarta, anatolia, n.d.), xxxviii. 
puncak epistemologi. Filsafat menurut Nursi mesti tunduk pada wahyu. ${ }^{22}$ Kebahagiaan sejati manusia akan datang ketika filsafat memiliki kesediaan untuk tunduk pada wahyu. Pemikiran Nursi terhadap keunggulan wahyu atas filsafat ini muncul karena perkembangan filsafat materialisme di Turki. Nursi memperlihatkan bagaimana ia memiliki penguasaan yang baik terhadap filsafat materialisme dan menegaskan posisinya untuk menentang filsafat tersebut.

Said Nursi bertekad untuk mengabdikan seluruh hidupnya agar mukjizat Alquran berkibar dan kaum Muslimin perpegang pada alquran. Nursi pada saat itu berjanji: "Saya akan membuktikan dan menunjukkan pada dunia bahwa Alquran adalah Matahari yang tidak akan mati sinarnya dan tidak mungkin bisa dimusnahkan. Saya akan menunjukkan bahwa Alquran adalah pengetahuan dan kemajuan sejati." 23 Bagi Said Nursi, tekad dan semangat menghidupkan cahaya Alquran adalah merupakan keharusan bagi seorang Muslim. Oleh Karena itu, dengan menyebarkan cahaya Alquran ini merupakan bentuk dari semangat kenabian. Memperjuangkan Islam adalah semangat kenabian, sebagaimana cucu dan keturunan dari nabi yang memperjuangkan Islam, itu semua adalah bentuk dari memperjuangkan risalah kenabian. Keyakinan atas nabi tidak sekedar mempercayainya semata melainkan mengikuti segala bentuk yang dilakukan oleh nabi.

Said Nursi mengajukan sanggahan kosmologis terhadap doktrin materialisme. Menurut Nursi, semua ciptaan di semesta jagad raya harus diatributkan kepada Zat Yang Maha Esa. Jika penciptaan alam semesta atau manusia tercipta dengan sendirinya dari materi atau secara kebetulan, maka pasti dibutuhkan cetakan alam sebanyak konstruksi dalam alam semesta dan tubuh manusia itu sendiri, dari yang terkecil hingga yang terbesar. ${ }^{24}$ Keteraturan yang terdapat pada alam, serta pengetahuan akan keseimbangan dan bentuk-bentuk yang terdapat pada alam menunjukkan adanya Tuhan yang mencipta dan menunjukkan adanya nabi. Tuhan menetapkan aturan yang terdapat dalam alam dan dalam agama yang kemudian disampaikan kepada utusan-Nya, yakni para nabi. Nabi membawa syariat untuk kemaslahatan umat manusia. Dalam kontaks ini, Said Nursi ingin menyampaikan bahwa alam dan agama atau alam dan ketuhanan merupakan sesuatu yang tak bisa dipisahkan. Adanya alam karena adanya Tuhan dan oleh karena itu manusia tidak sepantasnya untuk memisahkan Tuhan dengan kehidupan dunia. Pemahaman materialisme yang salah terkait kepada konsep alam sebagai sebuah sistem tertutup dengan sifat contingent yang dihilangkan. Menurut Nursi, alam bersifat contingent dan tidak bekerja dengan sendirinya. Semua fenomena alam, menurut Nursi, memiliki makna imanen dan makna transenden yang menuju pada pencipta alam dan hukumnya, yaitu Tuhan. Masalah yang paling mendasar dari materialisme bagi Nursi

${ }^{22}$ Akhmad Rizqon Khamami, "Membangun Peradaban dengan Epistemologi Baru: Membaca Pemikiran Said Nursi,” TSAQAFAH 11, no. 1 (November 30, 2015): 51, doi:10.21111/tsaqafah.v11i1.253.

23Vahide, Biografi Intelektual Badi'uzzaman Said Nurs; Transformasi Dinasti Usmani Menjadi Republik Turki, 41-42.

${ }^{24 B}$ Badi'uzzaman Said Nursi, The Flashes (Istanbul: Sozler Nesriyat, 2000), 237-238. 
adalah sikap abainya terhadap transendensi alam dan terlalu menekankan pada imanensi.

Selanjutnya, Nursi memberi ilustrasi tentang buku. Sebuah buku jika ditulis dengan sebuah tangan, maka untuk menuliskannya cukup diperlukan satu pena saja yang digerakkan oleh pengetahuan penulisnya untuk dituliskan sekehendaknya. Tetapi, jika buku tersebut tidak ditulis dengan sebuah tangan dan bukan hasil kreasi pena si penulis melainkan terbentuk dengan sendirinya, hal itu meniscayakan setiap huruf memiliki pena tersendiri. Jumlah pena yang ada harus sama dengan jumlah huruf tersebut. Dengan kata lain, harus ada pena sebanyak hurufnya sebagai ganti dari sebuah pena yang dipakai untuk menyalinnya. Lebih jauh ia mengajukan pertanyaan: "Bagaimana mungkin mereka (kaum materialis) dapat mengatakan bahwa buku alam semesta ini, yang di dalam tiap hurufnya dilukiskan sebuah buku, tidak mempunyai pengarang padahal mereka mengetahui bahwa satu huruf mengharuskan ada pengarangnya?" 25

Untuk menanggapi apa yang mereka maksudkan mengenai alam semesta bahwa alam semesta ini tanpa ada peran Tuhan, kita membutuhkan pengetahuan dari kenabian. Pengetahuan kenabian inilah yang nantinya akan berakhir kepada keimanan, yang oleh Nursi disebut sebagai kebahagiaan yang hakiki (manusia memiliki keimanan) bagi manusia, dan yang menolak (kekufuran) terhadap adanya peran Tuhan dan Nabi, itulah kesengsaraan yang sebenarnya. Dari penjelasan Nursi di atas tampaknya Nursi ingin mempertegas konsep ketuhanan klasik al-Asy'ariyah. Segala hal yang negatif dalam pemaknaan melekat pada materialisme dan materialisme merupakan sumber atas konflik.

Setelah mengetahui sebagian tesis besar dari paham materialisme dan kritikan Nursi terhadap paham tersebut, kita akan melihat ranah kenabian yang dijelaskan Nursi secara runtut sekaligus memberikan kritikan atas apa yang diajukan oleh Materialisme yang mengingkari kenabian Muhammad.

Petunjuk pertama: Urgensi kenabian Muhammad SAW Tidak ada keraguan bahwa Pemilik dan Pemelihara alam ini menciptakan seluruh makhluk berdasarkan pengetahuan dan berbuat penuh hikmah. Tuhan menata segala sesuatu berdasarkan pengetahuan bashirah, yaitu suatu cahaya di dalam hati yang mampu melihat kebenaran sejati, serta mengatur urusan guna memperlihatkan berbagai hikmah, tujuan dan kemaslahatan yang tampak dari segala sesuatu. ${ }^{26}$ Akal manusia terbatas untuk sampai pada hakikat tertinggi dan dalam konteks ini manusia membutuhkan perantara dengan kualitas akal yang melebihi akal manusia biasa dan perantara itu adalah nabi. Nabi diutus oleh Tuhan sebagai petunjuk untuk kemanusiaan. Akal manusia tidak akan sampai pada Tuhan sebelum meyakini nabi dan apa yang datang darinya.

Sang Pencipta mengetahui apa yang Dia perbuat, maka tentu Dia berbicara. Karena Dia berbicara, tentu pembicaraan-Nya diarahkan kepada makhluk yang dapat memahami-Nya; yaitu yang memiliki perasaan, kesadaran dan akal pikiran. Karena

\footnotetext{
${ }^{25}$ Said Nursi, Al-Matsnawi al-'Arabi al-Nuri, 16.

${ }^{26}$ Badi'uzzaman Said Nursi, Kumpulan Mukjizat Nabi Mubammad Saw (Banten: Risalah Nur, 2014), 7.
} 
Dia berbicara dengan makhluk yang mempunyai akal pikiran, tentu berbicara dengan manusia yang merupakan makhluk terbaik yang memiliki perasaan dan pemahaman serta menghimpun sifat-sifat tersebut. Manusia yang dimaksudkan disini adalah manusia yang layak menjadi mitra berbicara dari kalangan manusia sempurna yang memiliki potensi paling agung dan akhlak mulia serta dengan mereka yang pantas menjadi suri tauladan bagi umat manusia. Tentu tidak ada keraguan, Dia berbicara dengan Muhammad SAW yang kapasitasnya diakui oleh semua kalangan. Allah menjadikannya sebagai rasul dan menjadikan beliau sebagai teladan serta imam bagi seluruh manusia, dan hal itu benar-benar terbukti. ${ }^{27}$

Petunjuk kedua: "Katakanlah: Jika kalian mencintai Allah, ikuti aku, niscaya Allah mencintai kalian." Alquran dalam surah Ali-Imran ayat 3, pada petunjuk kedua, menunjukan bukti kuat atas kerasulan Muhammad SAW. Pasalnya, baik kreasi dan indahnya bentuk yang terdapat pada ciptaan menunjukan bahwa pada diri Penciptanya terdapat kehendak yang sangat kuat untuk memperbagus dan memperindah. hal tersebut menunjukan bahwa pada diri Pencipta terdapat rasa cinta yang tinggi dan keinginan yang suci untuk memperlihatkan kesempurnaan kreasi-Nya yang terdapat di dalam ciptaan-Nya. Rasa cinta itu mengarah dan memusat kepada manusia yang paling sempurna dan paling indah dengan perasaan pada pohon penciptaan. Buah tersebut merupakan bagian yang paling mencakup dari seluruh bagian pohon. Ia memiliki pandangan dan perasaan integral. ${ }^{28}$

Pribadi yang memiliki pandangan umum dan perasaan integral layak untuk menjadi mitra bicara Sang Pencipta Yang Maha Indah. Hal itu bertujuan untuk mengarahkan semua pandangan dan perasaannya yang integral tadi untuk menyembah penciptanya, mengapresiasi ciptaan-Nya, menghargai nikmat dan karunia-Nya. Tentulah mitra itu adalah yang paling dekat dan dicinta oleh-Nya. Terdapat dua bidang dan dua wilayah penting untuk dapat memahami maksud ini. Pertama, wilayah rububiyah yang sangat rapi dan menakjubkan berikut bidang kreasi yang sangat indah dan tertata. Kedua, wilayah ubudiyah yang bersinar dan cemerlang berikut bidang refleksi, apresiasi dan iman yang demikian komprehensif, luas, dan mencakup di mana wilayah ubudiyah ini bergerak dengan seluruh kekuatan atas nama wilayah pertama. ${ }^{29}$

Oleh karenanya dapat dipahami, bahwa pemimpin wilayah yang membantu maksud Sang Pencipta yang terkait dengan ciptaan-Nya memiliki hubungan yang sangat kuat dengan Sang Pencipta tadi. Di samping itu, ia juga dicinta dan disenangi oleh-Nya.

Apakah akal dapat menerima bahwa Pencipta seluruh ciptaan yang dihias dengan beragam keindahan, Pemberi seluruh nikmat, Pemelihara seluruh cita rasa yang terdapat pada makhluk, tidak lagi perduli? Logiskah bahwa Dia tidak memperdulikan ciptaan- $\mathrm{Nya}_{\mathrm{a}}$ yang paling indah, paling sempurna, yang selalu mengarah kepada-Nya dengan melakukan ibadah? Logiskah bahwa Dia tidak peduli dengan makhluk seperti itu yang telah mengguncang jagad raya dengan tahlil

${ }^{27}$ Ibid., 8.

${ }^{28}$ Badi'uzzaman Said Nursi, Al-Kalimat (Jakarta: Anatolia, 2011), 295.

${ }^{29}$ Ibid., 296. 
apresiasinya-Nya, dan takbir penghargaan-Nya terhadap berbagai keindahan kreasi Tuhan. Daratan dan lautan berguncang lantaran lantunan pujian, syukuran dan takbirNya atas nikmat Allah yang Maha Agung? Lalu mungkinkan Tuhan tidak mengarah kepadanya? Mungkinkah Dia tidak menurunkan wahyu kepadanya? Mungkinkah Dia tidak menjadikannya sebagai utusan dan tidak menebarkan akhlak-Nya yang baik dan indah kepada seluruh makhluk? Jawabannya tentulah tidak mungkin Dia tidak menurunkan firman-Nya padanya serta tidak menjadikannya utusan kepada seluruh manusia!. "Agama di sisi Allah hanyalah Islam." (QS. Ali Imran: 19) "Muhammad adalah utusan Allah. Orang-orang yang bersamanya demikian tegas terbadap orang kafir dan kasih sayang di antara mereka." (QS. al-Fath: 29). ${ }^{30}$

Selanjutnya, Nursi memberikan penegasan serta kritik kepada mereka yang menolak kerasulan Muhammad, dengan memberikan empat belas percikan penjelasan dan penegasan kerasulan Muhammad SAW. ${ }^{31}$

1. Muhammad SAW adalah imam bagi seluruh kaum beriman, kitab bagi semua manusia, pemimpin seluruh nabi dan semua wali. Ia adalah pohon bercahaya dimana akarnya yang kukuh berupa para nabi, ranting dan buah yang segar bercahaya berupa para wali. Setiap apa yang dilontarkan pasti diakui dan disaksikan oleh semua nabi dengan bersandar kepada mukjizat mereka, serta wali yang bersandar kepada karomah mereka. Pasalnya, ketika pengucapan lâ illâha illâ Allâh hal ini menegaskan tauhid yang terus berulang-ulang dan membuktikan sebuah kebenaran. Maka tidak ada ilusi yang bisa menyangkal penyataan yang telah didukung oleh kesaksian para saksi yang tak terhitung banyaknya.

2. Muhammad SAW dibenarkan oleh ratusan isyarat kitab samawi. Seperti kabar gembira dari Taurat, Injil, Zabur, serta kitab suci terdahulu selain itu kebenaran Muhammad dibenarkan oleh kejadian luar biasa, oleh peramal secara mutawatir serta dibenarkan oleh mukjizatnya.

3. Muhammad SAW adalah sosok luar biasa, karena keistimewaanya dan kemuliaannya, ia mampu membahas berita agung serta memecahkan teka-teki tentang rahasia penciptaan alam.

4. Apabila engkau melihat entitas dari luar cahaya petunjuknya, maka engkau akan melihat pemakaman umum didalamnya. Engkau akan melihat makhluk seperti orang asing dan musuh (tidak saling kenal). Engkau akan melihat hewan dan manusia laksana anak-anak yatim yang menangis karena kepergian dan perpisahan. Inilah gambaran orang yang tidak masuk kepada entitas cahaya beliau. Namun jika engkau perhatikan alam dengan cahaya beliau serta dengan teropong agamanya dalam wilayah syariatnya. Tempat pemakaman tadi akan berubah menjadi mesjid tempat berdzikir dan pemikir. Orang yang bermusuhan akan berubah menjadi kekasih dan persaudaraan. Dan yang terakhir engkau akan melihat hewan dan manusia yang seperti anak yatim, berubah menjadi kaum yang sedang berdzikir dalam tasbih mereka seraya bersyukur telah terlepas dari tugas.

30Ibid., 297.

${ }^{31}$ Ibid., 298-315. 
5. Dengan cahaya tersebut, gerakan keragaman dan berbagai perubahan entitas berganti dari kesia-siaan, permainan dan kebetulan menuju kepada ketentuan Tuhan, lembaran ayat penciptaan, serta cermin nama-nama Ilahi. Sehingga alam naik menjadi kitab hikmah-Nya yang abadi.

6. Muhammad SAW sebagai penyampai berita, ia menginformasikan dan memberikan kabar gembira tentang kebahagiaan abadi. Beliau menyingkap kasih sayang yang tak terhingga sekaligus mengumumkan dan menyeru manusia kepadaNya. Beliau menjadi petunjuk tentang indahnya kekuasaan Tuhan serta penyingkap perbendaharaan nama-nama Ilahi yang tersembunyi. Risalah yang dibawanya menjadi bukti kebenaran, lentera hakikat, mentari hidayah dan sarana menju kebahagiaan. Itulah bagaimana cahaya dan agamanya menjangkau Timur dan Barat dengan cepat. Sekitar separuh bumi dan umat manusia menerima penuh ketundukan persembahan hidayahnya dimana mereka rela mengorbankan nyawa untuknya.

7. Lihatlah ketika Muhammad SAW melenyapkan akhlak buruk di Jazirah yang luas itu, beragam bangsa yang begitu fanatik dan banyak menimbulkan permusuhan dalam sekejap bisa di lenyapkan dengan akhlak terpuji dan mulia. Sang guru dan pengajar peradaban ini telah berhasil merubahnya. Perhatikan! Kekuasaanya tidak hanya pada aspek lahiriah, namun beliau membuka qalbu dan akal, menundukan roh dan jiwa sehingga beliau menjadi orang yang dicintai oleh banyak qalbu, menjadi pengajar bagi akal mereka, serta mendidik jiwa mereka dan menguasai roh mereka.

8. Ketika ia melenyapkan tradisi fanatik di Jazirah itu dengan waktu yang singkat, beliau menggantinya dengan akhlak mulia pada karakter mereka. Ribuan pencapaian luar biasa dari apa yang kita lihat, barang siapa yang belum melihat era bahagia, maka kami akan masukan kepada matanya Jazirah sekaligus menantangnya. Hendaknya ia mencoba melakukan hal tersebut disana. Bawalah seratus filosof ke daerah tersebut dan bekerjalah di dalamnya selama seratus tahun. Apakah mudah bagi mereka untuk melakukan satu saja dari seratus bagian yang dilakukan oleh rasul dalam setahun diukur dengan kondisi ketika itu?

9. "Ia tidak lain merupakan wahyu yang disimpan padanya.",32 Muhammad SAW menyampaikan apa yang mesti ia sampaikan tanpa ragu dan rasa bimbang serta tanpa dibuat-buat. Beliau mengungkapnya tanpa peduli meski ada hambatan, kebenaran tidak membutuhkan pemalsuan. Pandangan hakikat lebih mulia untuk di manipulasi. Jalan yang benar tidak membutuhkan manipulasi serta pandangannya yang tajam dapat membedakan antara imajinasi dan hakikat.

10.Jika ada yang berkata kepadamu "Jika engkau korbankan sebagian usiamu atau setangah hartamu tentu akan datang seorang dari bulan dan planet yang memberikan informasi kepadamu tentang hal-hal yang menakjubkan serta memberitahu tentang masa depan mu." Ku kira engkau akan mau berkorban untuknya. Engkau akan rela memenuhi keingintahuanmu dengan mengorbankan setengah usia dan hartamu: sementara engkau tidak peduli dengan sabda nabi saw.

${ }^{32}$ QS. an-Najm:4 
yang dibenarkan oleh semua nabi, kaum Shiddiqin, wali dan para ahli hakikat yang telah menyaksikan. Beliau menerangkan kondisi kerajaan-Nya dan beliau memberitahukan tentang alam yang menjadi tempat kejadian berbagai hal luar biasa, di mana kalau pun bumi terbelah dan gunung-gunung berterbangan seperti awan, hal itu masih belum seberapa. Perhatikan firman-firman Allah "Apabila matahari telah digulung.", "Apabila langit terbelah.",34 "Apabila bumi digoncang dengan segoncang-goncangnya.",35 Beliau menceritakan tentang realitas masa depan dimana masa depan dunia jika dibandingkan dengannya hanyalah satu tetes fatamorgana yang tidak ada artinya jika diukur dengan lautan tak bertepi. Beliau memberitahukan tentang alam kebahagiaan di mana kebahagiaan duniawi jika diukur dengannya hanyalah seberkas kilat yang cepat menghilang diukur dengan mentari abadi.

11.Dibalik hijab alam terdapat berbagai hal yang menakjubkan yang menantikan dan menatap kita. Untuk memberitahukan semua itu harus ada sosok luar biasa yang dapat menyaksikan. Sosok itu adalah Muhammad SAW. Selain menyaksikan dan bersaksi, ia memberitahukan tentang siapa saja yang disukai oleh Tuhan Pemelihara alam semesta dari kita. Maka sungguh rugi orang yang lalai, tersesat, serta aneh mengapa sebagian besar manusia dungu. Bagaimana tidak peduli dengan berbagai hal yang menakjubkan yang terdapat pada sosok semacam beliau. Mestinya orang sepertinya layak dibela dan segera dihampiri dengan meninggalkan segala sesuatu.

12.Perlu diketahui pribadi beliau yang tampak dengan moralitasnya, yang dikenal dunia dengan ketinggian sifatnya, disamping merupakan petunjuk yang benar akan keesaan Tuhan dan dalil kebenaran tauhid, beliau juga merupakan petunjuk terang dan dalil cemerlang yang menjelaskan tentang kebahagiaan abadi. Lebih dari itu, sebagaimana lewat dakwah dan petunjuknya beliau menjawab sebab yang mengantarkan kepada kebahagiaan abadi. Lewat doa dan pengabdiannya beliau juga menjadi sebab terwujudnya kebahagiaan tersebut. Engkau dapat melihatnya ketika dalam "sholat besar" yang menjadi kekuasaannya ia merubah Jazirah Arab; bahkan seluruh dunia menjadi sosok yang melakukakn shalat semacam itu. Shalat dengan jamaah begitu banyak, seolah-olah beliau menjadi imam dalam mihrab masanya dan diikuti oleh semua manusia dari sejak Adam sampai akhir zaman, ketika beliau berdoa semua ikut berdoa bersamanya termasuk langit dan seluruh entitas.

13.Sungguh menakjubkan apa yang diminta oleh sosok yang tegak diatas bumi yang membuat seluruh nabi beserta seluruh manusia mulia berbaris dibelakangnya. Beliau mengangkat tangan mengarah kepada arasy yang agung lalu berdoa dengan diamini oleh jin dan manusia. Beliau adalah manusia paling mulia, makhluk paling istimewa kebanggaan seluruh alam di sepanjang zaman. Beliau meminta syafaat lewat seluruh nama Tuhan yang tampak pada cermin entitas. Jika risalah beliau

${ }^{33}$ QS. at-Taqwir:1

${ }^{34}$ QS. al-Infitar:1

${ }^{35}$ QS. al-Zalzalah:1 
menjadi sebab dunia ini dijadikan sebagai tempat ujian dan penghambaan, doa beliau menjadi sebab akhirat dijadikan sebagai tempat pemberian balasan dan ganjaran. Keteraturan yang luar biasa, rahmat-Nya yang demikian luas, ciptaan-Nya yang sangat sempurna tanpa cacat, al-Ghazali berkata, "tidak ada yang lebih indah darinya." Mungkinkah itu digantikan oleh keburukan, kezaliman, dan kerancuan? Pasalnya, jika mereka tidak mau mendengar bahkan menolak sosok manusia yang agung ini, hal ini merupakan sesuatu yang paling buruk dan cacat. Jika engkau wahai Barat ingin menjangkau seluruhnya, maka itu tidak akan mampu.

14.Perlu diketahui bahwa Alquran yang engkau ingin jauhkan dari tanah kami, dan engkau ingin kami membencinya itu merupakan lautan mukjizat dan mukjizat terbesar dengan sangat tegas menetapkan kenabian Muhammad SAW serta keesaan Ilahi. Ia mengetengahkan sejumlah argumen, memberikan berbagai petunjuk, serta memperlihatkan dalil-dalil yang bersifat mandiri. Ia adalah terjemah azali bagi buku alam yang besar. Ia juga penjelas bagi berbagai pembendaharaan nama-nama Ilahi yang tersembunyi dalam lembaran langit dan bumi. Ia kunci bagi berbagai hakikat yang tertutup dalam baris-baris kejadian. Ia adalah khazanah kebaikan rahmani dan penyampaian azali yang bersumber dari alam gaib. Ia pilar dan mentari bagi dunia Islam dan peta bagi alam ukhrawi. Selain itu ia adalah kitab syariat, kitab hikmah, kitab dzikir, doa, dan ibadah, ia juga kitab dakwah, ia seperti rumah suci bagi setiap jalan dari berbagai kelompok yang berbeda terdiri dari wali, kaum Siddiqin, ahli makrifat, hakikat sebuah risalah yang sesuai untuk menerangi dan menggambarkan jalan tersebut sehingga ia menjadi seperti kumpulan risalah. Perhatikan! Salah satu dari kemukjizatan dibalik pengulangan ayat Alquran yang di anggap cacat oleh mereka yang kurang memahami retorika. Pengulangan ayat-ayat itu bertujuan untuk memudahkan bagi pembaca nya, karena Tuhan yang Maha Bijaksana mengetahui, tidak mungkin semua orang akan selalu dapat membaca keseluruhan Alquran oleh karena nya Allah memasukan sebagian besar maksud Alquran dalam sebagian surat, dengan tujuan untuk memudahkan jalan bagi orang yang tidak bisa mengakses. Dia mengulang persoalan tauhid, kebangkitan, dan kisah Musa as. sama seperti halnya jasmani juga perlu "Huwa Allah", pengulangan ini juga bagi roh seperti kebutuhan tubuh terhadap udara, begitu pun bismillah. Selain itu Alquran merupakan peletak dasar agama yang agung dan kukuh, perubahan tatanan sosial manusia serta jawaban terhadap berbagai pertanyaan dari beragam kelompok masyarakat yang terus berulang. Maka dari itu diperlukan pengulangan bertujuan untuk menegaskan, menguatkan dan menetapkan. Perhatikanlah perkataan filsuf bodoh itu terkait matahari. Ia berkata: matahari adalah benda besar yang berasal dari cairan api, ia berotasi pada orbitnya. Percikan api, yaitu bumi dan sejumlah planet lain berterbangan darinya. Benda-benda angkasa yang berbeda-beda ukuran besarnya sekian dan substansinya adalah demikian. Jika kita perhatikan perkataannya, tidak ada yang kau dapatkan dari pembahasan di atas kecuali kebingungan dan keterperanjatan yang luar biasa. Ia tidak memberimu kesempurnaan ilmiah, cita rasa spiritual, tujuan kemanusiaan, dan manfaat kegamaan. Itulah standar untuk menetapkan nilai berbagai persoalan filsafat yang secara lahir tampak indah namun batinnya kosong berisi kebodohan 
oleh karena itu engkau tertipu oleh kemilau lahiriahnya lalu berpaling dari penjelasan Alquran. Aku (Nursi) berdoa, "Ya Allah, jadikan Alquran sebagai obat segala penyakit bagi kami dan pemberi ketentraman di saat hidup dan mati. Jadikan ia sebagai teman pendamping kami di dunia, pemberi kedamaian di kubur, pemberi syafaat di hari kiamat, cahaya saat berada di jembatan shirath, tameng dan hijab dari neraka, sahabat menuju surga, petunjuk kepada berbagai kebaikan, serta sebagai pemimpin dengan karunia, pujian, kemurahan, dan rahmat-Mu wahai dzat yang Maha Pengasih dan Penyayang."

Setelah menuliskan 14 percikan di atas, Nursi lebih lanjut menjelaskan bagian terakhir yang di atas, yaitu tentang kemilau mukjizat pengulangan ayat Alquran pada buku lainnya, tepatnya pada buku al-Matsnawi an-Nuri. Kiranya penulis tidak akan menjelaskan secara detail mengenai kelanjutannya. Hanya saja Nursi menjelaskan 15 dari berbagai macam kemukjizatan Alquran yang jumlahnya mencapai $40 .{ }^{36}$ Oleh karena itu, penulis merasa 14 percikan di atas yang disampaikan Nursi sudah dapat memberikan jawaban atas apa yang mereka (materialisme) sangka, serta 14 percikan di atas telah memberikan cahaya kembali kepada tanah Turki yang terasa sampai saat ini.

\section{Misi Kenabian}

Pembicaraan mengenai misi kenabian, seperti yang diterangkan dalam ayatayat dan hadits, sebagaimana firman Allah pada Alquran Surah Ali-Imran: 164 "Sesungguhnya Allah telah memberi karunia kepada orang-orang yang beriman ketika Allah mengutus di antara mereka seorang rasul dari golongan mereka sendiri, yang membacakan kepada mereka ayat-ayat Allah, membersihkan (jiwa) mereka, dan mengajarkan kepada mereka al-Kitab dan al-Hikmah. Dan sesungguhnya sebelum (kedatangan nabi) itu, mereka adalah benar-benar dalam kesesatan yang nyata." Serta terdapat hadits dari buku Bihâr al-anwâr yang dikutip dari buku Ibrahim Amini, dimana hadits ini diriwayatkan oleh Imam Ali as. "Nabi bersabda: 'Aku wasiatkan akhlak yang baik kepada kalian, yang karenanya Allah mengutusku.' Lanjutnya, 'Aku diutus kepada kebaikan dan dengan membawa kemuliaan akhlak." ${ }^{37}$

Misi para nabi dapat di ambil secara singkat, sebagaimana Ibrahim Amini berpendapat "sebetulnya para nabi itu mempunyai dua misi besar diantaranya: misi spiritualisasi masyarakat dan reformasi sosial." Misi yang pertama mengarahkan umat kepada nilai dan pentingnya kehidupan spritualitas, hal ini bertujuan memberikan petunjuk kepada hal-hal yang melahirkan penyempurnaan jiwa dan kedekatan dengan Allah serta menjamin kebahagiaan ukhrawi. Lebih lanjut, bertujuan untuk menjelaskan dan memperingatkan sebab-sebab kemerosotan dan kesengsaraan alam akhirat.

Misi yang kedua, dimana misi ini diberikan kepada kehidupan duniawi masyarakat. Para nabi memberikan perhatian sepenuhnya kepada perbaikan urusanurusan sosial dan ekonomi. Hal ini diperhatikan oleh para nabi agar tatanan masyarakat dapat tercegah dari kezaliman dan penyimpangan, untuk itu nabi

${ }^{36}$ Said Nursi, Al-Kalimat, 315.

${ }^{37}$ Ibrahim Amini, Mengapa Nabi Diutus (Jakarta: Al-Huda, 2006), 55.

Khazanah, Vol. 18 (1), 2020 
menetapkan undang-undang agar adanya keadilan bagi masyarakat. ${ }^{38}$ Caknur, disisi lain, sebagaimana dikutip dalam buku Mengenal Islam Jalan Tengah, menyebutkan bahwa di dalam kitab suci (Alquran) disebutkan ada pesan historis para nabi dan rasul. Diantaranya mengajarkan ketuhanan yang maha Esa serta memberantas tirani. Salah satu dari misi para nabi juga menegakan keadilan. Menurut Cak Nur, penegakan keadilan merupakan tugas yang suci, misi sosial semua nabi, mulai dari Adam sampai Muhammad. Alquran banyak sekali berbicara mengenai keadilan dengan nada yang keras, maka dari itu peran para abi dikatakan bahwa:

Sejarah para Nabi adalah memperjuangkan untuk 'menyembuhkan' masyarakat dari penyakit sosial yang sudah akut, yaitu dzalim dan tidak adil. Bahkan didalam ajaran Islam pun keadilan dipandang sebagai hukum kosmik jagad raya. Sebab, melanggar keadilan berarti melanggar hukum kosmik, dosa ketidakadilan pun akan mempunyai dampak yang serius terhadap tatanan masyarkat. Sebagai hukum kosmik, sangat berlaku, bukan hanya bagi yang beragama, namun juga yang tidak beragama. ${ }^{39}$

Pada sisi lain, bagi Nursi, misi para nabi adalah menyampaikan pesan-pesan Ilahi serta merubah tatanan masyarakat dan mereformasi sosial menuju perubahan yang telah dicita-citakan. Menurut Nursi, Nabi Muhammad sangat layak digelari seorang reformis karena selain ia berhasil mereformasi tatanan masyarakat pada eranya, terdapat juga sejumlah bukti arkeologis berupa bebatuan dan nisan yang di atasnya bertuliskan dengan aksara kuno yang dapat ditemukan di banyak tempat di dunia Islam, tertulis Mubammad Musblih Amîn (Muhammad seorang reformis yang amanah)..$^{40}$ Oleh karena itu, Muhammad sangat layak disebut sebagai reformis yang amanah, pasalnya ia memiliki sifat tersebut. ${ }^{41}$ Rasul SAW adalah pemimpin seluruh rasul, imam bagi seluruh nabi, tambatan hati orang-orang suci, pembimbing seluruh mursyid, orang yang paling dekat dengan Allah diantara orang yang dekat dengan-Nya, dan ia adalah makhluk paling sempurna. Hal tersebut merupakan bukti kuat bahwa ketuhanan tidak terwujud tanpa kerasulan. ${ }^{42}$

Pada buku lain, al-Lama'at, Nursi menjelaskan misi dan tugas kenabian Muhammad SAW. bahwa nama al-Hakim secara jelas mengharuskan dan mengkonsekuensikan kenabian dan kerasulan Muhammad SAW. Sebuah kitab yang bermakna mengharuskan keberadaan seorang pengajar yang jenius untuk mengajarkannya, karena keindahan yang menakjubkan mengharuskan keberadaan sebuah cermin agar menjadi tampak sekaligus menampakan keindahannya, serta karena ciptaan yang sempurna mengharuskan keberadaan orang yang menyeru kepadanya, maka harus ada antara umat manusia—yang menjadi sasaran kitab jagad raya ini berisi ratusan makna dan hikmah mendalam pada setiap hurufnya—seorang

${ }^{38}$ Ibid., 53-56.

${ }^{39}$ M. Subhi Ibrahim dkk, Mengenal Islam Jalan Tengab: Kenabian, Konsep Keselamatan Islam (Jakarta: Dian Rakyat, 2012), 95-96.

40Said Nursi, Kumpulan Mukjizat Nabi Mubammad Saw, 218.

${ }^{41}$ Ibid.

${ }^{42}$ Said Nursi, Al-Kalimat, 73. 
pemimpin yang paling sempurna dan pengajar yang paling agung. Penjelasan Said Nursi terkait nama al-Hakim:

1. Untuk membimbing manusia kepada berbagai hikmah suci dan hakiki yang terdapat dalam kitab besar itu.

2. Untuk mengajarkan berbagai hikmah yang terbesar dalam seluruh sisinya.

3. Untuk menjadi tempat munculnya seluruh tujuan Tuhan dalam menciptakan alam bahkan menjadi sebab kemunculannya.

4. Untuk menunjukan kesempurnaan ciptaan dan keindahan nama-nama-Nya yang mulia seperti yang ingin ditampakan Tuhan sehingga ia menjadi cermin bening yang menampilkan kesempurnaan dan keindahan-Nya yang luar biasa itu.

5. Untuk memberikan pengabdian menyeluruh atas nama seluruh makhluk terhadap seluruh bentuk kekuasaan Tuhan yang luas serasa membangkitkan rasa rindu dan cinta di seluruh alam baik di darat maupun di laut dengan memalingkan perhatian seluruh makhluk kepada Sang Pencipta yang Maha Agung lewat dakwah, doa, tablil, tasbih, dan taqdis di mana seluruh sisi langit dan bumi mendengarkan.

6. Untuk menjukan berbagai pelajaran suci dan petunjuk penuh hikmah yang berasal dari Alquran ke telinga semua orang yang berakal.

7. Untuk menjelaskan berbagai maksud suci Sang Pencipta yang Maha Bijak dalam bentuk yang paling indah dan paling agung lewat Alquran yang agung.

8. Untuk menyambut seluruh wujud hikmah mendalam di samping keindahan dan keagungan-Nya yang tampak di seluruh cakrawala dengan sambutan paling sempurna. $^{43}$

Inilah kiranya misi dan tugas yang dibawa oleh Nabi Muhammad SAW. Keberadaan beliau seperti kebutuhan dan keharusan akan adanya matahari. Oleh karena itu, sebagaimana matahari mengharuskan adanya sinar dan sinar tersebut mengharuskan adanya siang, maka berbagai hikmah yang tersebar di seluruh alam mengharuskan kehadiran Muhammad SAW sebagai seorang nabi dan rasul, sebagaimana manifestasi agung dari nama al-Hakam dan al-Hakim dalam wilayahnya yang paling luas mengharuskan kehadiran Muhammad SAW. Maka sebagian besar nama-nama Tuhan seperti Allah, ar-Rahman, ar-Rabim, al-Wadud, al-Mun'im, al-Karim, al-Jamil, dan ar-Rabb, juga betul-betul mengharuskan keberadaan Muhammad dalam sebagian besar manifestasinya di seluruh bumi. ${ }^{44}$

Selanjutnya, terdapat keharmonisan antara tugas atau misi kenabian Muhammad saw dengan persoalan-persoalan sekunder. Rasulullah saw telah memperlihatkan rasa cintanya yang besar terhadap sesuatu yang bersifat khusus, padahal misi kenabian yang beliau bawa bersifat umum dan komprehensif. Secara lahiriah, kesannya rasa cinta dan kasih sayang terhadap sesuatu yang bersifat khusus itu tidak sesuai dengan tugas kenabian beliau yang agung. Namun, sebenarnya unsur

${ }^{43}$ Badi'uzzaman Said Nursi, Al-Lama'at: Menikmati Hidangan Langit (Jakarta: Robbani Press, 2010), 685 .

44Ibid., 686.

Khazanah, Vol. 18 (1), 2020 
yang bersifat khusus tersebut menggambarkan satu tepi dari sebuah rangkaian yang pada masa selanjutnya akan mengemban seluruh misi kenabian. ${ }^{45}$

Rasul saw memberikan contoh yang menunjukkan rasa cinta dan perhatiannya yang besar kepada Imam Hasan dan Husein di saat mereka masih muda belia bukan semata-mata karena naluri kasih sayang dan rasa cinta yang muncul dari adanya hubungan keluarga. Tetapi karena keduanya merupakan pangkal dari rangkaian cahaya yang membawa salah satu misi kenabian beliau yang agung, keduanya menjadi sumber dari sebuah komunitas agung yang mewarisi kenabian, serta menjadi cermin dan teladan kenabian. Sikap Rasul yang memeluk Hasan ra. serta mencium kepalanya dengan penuh kasih sayang disebabkan oleh karena banyak sekali para pewaris kenabian, pembawa syariat agung, yang berasal dari anak cucu Hasan serta bersumber dari keturunannya yang bersinar dan penuh berkah. Diantaranya adalah Syaikh Abdul Qodir al-Jailani. Dengan penglihatan kenabian, beliau telah menyaksikan tugas suci yang diemban oleh orang-orang itu di masa mendatang. Sehingga beliau menghargai dan menghormati jasa pengabdian mereka. Ciuman Rasul kepada kepala Hasan adalah bentuk penghormatan dan dukungan. ${ }^{46}$

Ketika Rasul saw memberikan perhatian dan cinta yang begitu mendalam terhadap Husein ra. sebetulnya hal itu diperuntukan bagi keturunannya, Yaitu para imam agung yang berposisi sebagai pewaris kenabian seperti Zainal Abidin dan Ja'far ash-Shodiq. Beliau telah mencium leher Husein serta beliau telah memperlihatkan kasih sayang dan perhatiannya yang besar kepadanya keluarga nabi bagaikan Mahdi yang meninggikan panji Islam dan mengemban tugas kerasulan sesudah beliau. Mata hati beliau mampu menembus serta memperhatikan peristiwa yang tertutup tirai masa lalu yang gelap sejak nabi Adam as, bahkan beliau juga mampu menyaksikan Allah Taala. Maka dengan itu tidaklah aneh jika penglihatan rasul mampu menyaksikan para tokoh yang agung dan imam pewaris para kenabian yang berasal dari keturunan Hasan dan Husein di masa depan. Atas dasar itulah Nabi mencium Hasan, sebab terdapat bagian besar yang dimiliki oleh Syeikh Abdul Qodir al-Jailani. ${ }^{47}$

Nabi SAW adalah utusan Allah yang mulia, disebutkan pula bahwa siapa yang tidak buta dengan melihat tanda-tandanya akan memahami bahwa bergerak dengan perintah Raja. Ia merupakan pelayan-Nya yang istimewa. alam yang indah ini serta penciptaanya yang suci pasti memiliki utusan yang mulia semacam beliau sebagaimana cahaya yang tidak bisa dipisahkan dengan mentari. Sebab, apabila mentari menyebarkan cahaya, maka Tuhan juga memperlihatkan diri dengan mengutus para utusan yang mulia. ${ }^{48}$

\section{Simpulan}

Dari uraian di atas dapat disimpulkan bahwa Nabi menurut Said Nursi adalah orang-orang yang mulia, yang membawa pesan-pesan kebenaran dan petunjuk yang

\footnotetext{
${ }^{45}$ Ibid., 43.

46Ibid.

${ }^{47}$ Ibid., 44.

${ }^{48}$ Ibid. 71 .
} 
agung dari Tuhan. Nabi merupakan pohon di mana akarnya yang kukuh dan bercahaya, yang memperkenalkan manusia kepada Tuhan. Kenabian adalah sisi diantara para pembawa petunjuk tauhid yang bercahaya, posisi kenabian pada manusia merupakan rangkuman kebaikan serta landasan kesempurnaan. Agama yang benar merupakan indeks kebahagiaan, iman merupakan kebaikan murni dan keindahan mutlak. Kebaikan yang cemerlang, limpahan yang luas dan mulia, serta kesempurnaan yang utama tampak di alam ini, tentulah hakikat kebenaran ada pada sisi kenabian dan para nabi.

Misi para nabi adalah menyampaikan pesan-pesan Ilahi serta merubah tatanan masyarakat dan mereformasi sosial menuju perubahan yang telah dicita-citakan. Menurut Nursi, Nabi Muhammad sangat layak digelari seorang reformis, karena selain ia berhasil mereformasi tatanan masyarakat pada eranya, terdapat juga sejumlah bukti arkeologis berupa bebatuan dan nisan yang di atasnya bertuliskan dengan aksara kuno yang dapat ditemukan di banyak tempat di dunia Islam, tertulis Mubammad Mushlih Amîn (Muhammad seorang reformis yang amanah).

\section{Daftar Pustaka}

Amini, Ibrahim. Mengapa Nabi Diutus. Jakarta: Al-Huda, 2006.

Bagus, Lorens. Kamus Filsafat. Jakarta: Gramedia, 2005.

Basit, Musa al-. Said Nursi's Approach to The Stories of The Qur'an. In A Contemperary Approach to Understanding The Qur'an: The Example of The Risale-i Nur. Istanbul: Sozler Nesyriyyat, 2000.

Faiz, Muhammad. "Risalah Nur Dan Gerakan Tarekat Di Turki: Peran Said Nursi Pada Awal Pemerintahan Republik." Al-A'raf: Jurnal Pemikiran Islam dan Filsafat 14, no. 1 (June 27, 2017): 23. doi:10.22515/ajpif.v14i1.588.

Faiz, Muhammad, and Ibnor Azli Ibrahim. "Unsur Sufisme Dalam Konsep Pendidikan Said Nursi" 4, no. 2 (2015): 16.

Gaarder, Jostein. Dunia Sopbie. Bandung: Mizan, 1997.

Hardiman, F. Budi. Filsafat Modern. Jakarta: Gramedia, 2007.

Ibrahim, M. Subhi, dkk. Mengenal Islam Jalan Tengah: Kenabian, Konsep Keselamatan Islam. Jakarta: DIan Rakyat, 2012.

Junaidi, Alkan. "Eksistensi Tuhan Menurut Said Nursi” 1, no. 1 (2016): 9.

Khamami, Akhmad Rizqon. "Membangun Peradaban dengan Epistemologi Baru: Membaca Pemikiran Said Nursi." TSAQAFAH 11, no. 1 (November 30, 2015): 51. doi:10.21111/tsaqafah.v11i1.253.

Ramadlani, Ilyas Fahmi. "Perjuangan Badiuzzaman Said Nursi dalam Membendung Arus Sekularisasi di Turki" 3, no. 1 (2019): 8.

Ridwanuddin, Parid. "Ekoteologi Dalam Pemikiran Badiuzzaman Said Nursi." LENTERA: Jurnal Ilmu Dakwah dan Komunikasi 1, no. 01 (May 12, 2017). doi:10.21093/lentera.v1i01.832.

Said Nursi, Badi'uzzaman. Al-Kalimat. Jakarta: Anatolia, 2011.

- Al-Lama'at: Menikmati Hidangan Langit. Jakarta: Robbani Press, 2010. - Al-Matsnawi al-'Arabi al-Nuri. Jakarta: Anatolia, n.d. 
Fuad Mahbub Siraj; Muhammad Husni

- Kumpulan Mukjizat Nabi Muhammad Saw. Banten: Risalah Nur, 2014.

—. The Flashes. Istanbul: Sozler Nesriyat, 2000.

Salih, Ihsan Kasim. Said Nursi Pemikir Dan Sufi Besar Abad 20. Jakarta: Murai Kencana, 2003.

Syauqi, Muhammad Labib. "Mengenal Risalah Nur Karya Said Nursi Dan Metodologi Penafsirannya." MAGHZA: Jurnal Ilmu Al-Qur'an dan Tafsir 2, no. 1 (May 25, 2018): 109-24. doi:10.24090/maghza.v2i1.1547.

Titus, Harold H. Persoalan-Persoalan Filsafat. Jakarta: Bulan Bintang, 1984.

Vahide, Sukran. Biografi Intelektual Badi'uzzaman Said Nurs; Transformasi Dinasti Usmani Menjadi Republik Turki. Jakarta: Anatolia, 2007.

Zarkasyi, Hamid Fahmy, Jarman Arroisi, Amal Hizbullah Basa, and Dahniar Maharani. "Konsep Psikoterapi Badiuzzaman Said Nursi dalam Risale-i Nur." TSAQAFAH 15, no. 2 (November 4, 2019): 215. doi:10.21111/tsaqafah.v15i2.3379. 